\title{
URGENSI PENETAPAN HAK ULAYAT MASYARAKAT HUKUM ADAT TERKAIT KEBIJAKAN PELAYANAN PERTANAHAN DI PAPUA
}

\author{
Arif Rahmadi \\ Kantor Wilayah Badan Pertanahan Nasional Provinsi Papua \\ Jalan Tanjung Ria No. 26 Base-G Jayapura Papua \\ Koresponden email: arifrahmadipati@gmail.com
}

Naskah diterima: 17 Januari 2022; revisi: 7 Februari 2022; disetujui: 14 Februari 2022

\begin{abstract}
The existence of indigenous peoples, which until now has not received recognition through regional regulations, creates uncertainty which is one of the causes of agrarian conflicts in several regions in Papua. Based on these conditions, the purpose of this study is to provide an overview of the progress and urgency of the customary land tenure of indigenous people related to land administration policies in Papua. The author uses a normative legal research method, with a case study approach and qualitative data analysis that relies on secondary data obtained through literature study with stages including 1) data collection; 2) data analysis; and 3) concluding various literature which relevant to the problem formulation. Until now, there are no districts in Papua that have regional decree regarding the recognition of the customary land tenure of indigenous peoples. Various agrarian conflicts are caused by the customary land tenure uncertainty. Recognition of customary land tenure becomes very important to be carried out immediately because 1) the mandate of the Special Autonomy Law; 2) can reduce agrarian conflicts; 3) the first-time land registration will be easier, and 4) the land recognition is a necessity of the state. The author suggests that regional heads need to internalize this recognition into their vision and mission, prioritize the budget for its implementation, and engaged with various parties related to the existence of customary land tenure of indigenous peoples.
\end{abstract}

Keywords: Recognition, Customary Land Tenure, Indigenous Peoples, Land Administration, Papua

\begin{abstract}
Abstrak: Keberadaan masyarakat hukum adat yang hingga saat ini belum mendapatkan pengakuan melalui peraturan daerah menimbulkan ketidakpastian yang menjadi salah satu penyebab terjadinya sengketa pertanahan di berbagai wilayah di Papua. Berangkat dari kondisi tersebut, tujuan penelitian ini adalah untuk memberikan gambaran mengenai perkembangan dan urgensi penetapan hak ulayat masyarakat hukum adat terkait kebijakan pelayanan pertanahan di Papua. Penulis menggunakan metode penelitian hukum normatif, dengan pendekatan studi kasus dan analisis data kualitatif yang bertumpu pada data sekunder yang diperoleh melalui studi pustaka dengan tahapan meliputi 1) pengumpulan data; 2) analisis data; dan 3) penarikan kesimpulan dari berbagai literatur yang relevan dengan permasalahan penelitian. Hingga saat ini belum ada kabupaten/kota di Papua yang telah menetapkan peraturan daerah tentang pengakuan hak ulayat masyarakat hukum adat. Padahal, berbagai sengketa pertanahan disebabkan belum adanya kejelasan mengenai hak ulayat masyarakat hukum adat. Penetapan hak ulayat menjadi sangat penting untuk segera dilakukan karena 1) amanat UU Otsus; 2) dapat mengurangi sengketa pertanahan; 3) pendaftaran tanah pertama kali akan semakin mudah; dan 4) penetapan tersebut merupakan kebutuhan negara. Penulis menyarankan kepala daerah perlu menginternalisasi penetapan ini ke dalam visi misi dan memprioritaskan anggaran untuk pelaksanaannya serta membangun komunikasi dengan berbagai pihak terkait penelitian keberadaan hak ulayat masyarakat hukum adat.
\end{abstract}

Kata Kunci: Penetapan, Hak Ulayat, Masyarakat Hukum Adat, Pelayanan Pertanahan, Papua 


\section{A. Pendahuluan}

Provinsi Papua (selanjutnya disebut dengan Papua) adalah salah satu Provinsi di wilayah Negara Kesatuan Republik Indonesia. Data luas daerah provinsi yang dipublikasi oleh Badan Pusat Statistik (2019) menunjukkan bahwa wilayah yang terletak di ujung timur Indonesia ini memiliki luas 312.224,37 $\mathrm{km}^{2}$ atau sekitar $16 \%$ dari luas wilayah Indonesia. Papua terbagi dalam 28 kabupaten dan 1 kota, dengan pusat pemerintahan yang terletak di Jayapura juga merupakan salah satu provinsi dengan otonomi khusus yang sebagaimana diatur dengan Undang-Undang Nomor 21 Tahun 2001 (UU Otsus). Topografi wilayah yang sangat beragam, mulai dari pantai, dataran, hingga bukit dan pegunungan tersebar di Papua. Diantaranya, terdapat empat kabupaten dengan tinggi wilayah lebih dari 2.000 mdpl yakni 1) Kabupaten Puncak berada pada ketinggian $2.303 \mathrm{mdpl}$; 2) Kabupaten Puncak Jaya berada pada ketinggian 2.119 mdpl; 3) Kabupaten Lanny Jaya berada pada ketinggian 2.117 mdpl; dan 4) Kabupaten Intan Jaya berada pada ketinggian 2.101 mdpl (Badan Pusat Statistik, 2021). Sebagian besar tutupan lahan di wilayah Papua masih berupa hutan (Kementerian Lingkungan Hidup dan Kehutanan, 2015).

Kondisi tersebut mempengaruhi pola kehidupan masyarakat di Papua, mereka tinggal secara berkelompok sehingga terbentuk wilayah adat yang dihuni oleh sekelompok suku tertentu. Solossa (2021), pada Rapat Koordinasi Gugus Tugas Reforma Agraria Kabupaten Sarmi 2021 menyampaikan bahwa masyarakat hukum adat Papua (Papua dan Papua Barat) terdiri dari 7 wilayah adat. Masing-masing wilayah adat, terdiri dari sukusuku yang berbeda dengan wilayah adat lainnya.

Setiap masyarakat adat hidup dalam wilayah tertentu dan tunduk dengan adat tertentu yang dijunjung tinggi oleh mereka. Hal tersebut menjadi salah satu penyebab terjadinya sengketa antara suku dengan wilayah yang berbatasan. Sebagai contoh, pada tahun 2020 terjadi bentrok antara Suku Nafri dan Suku Enggros yang disebabkan karena adanya permasalahan hak tanah di sekitar Jembatan Youtefa, Jayapura. Selain faktor adanya klaim sepihak oleh salah satu suku, hal tersebut juga terjadi akibat belum adanya penetapan hak ulayat masyarakat hukum adat yang di dalamnya termasuk wilayah tertentu yang menjadi bagian dari hak ulayat suatu masyarakat hukum adat oleh pemerintah daerah sebagaimana diatur dalam Peraturan Daerah Khusus Provinsi Papua Nomor 23 Tahun 2008 (Perdasus 23 tahun 2008).

Penetapan hak ulayat masyarakat hukum adat berkaitan dengan pelayanan pertanahan. Dalam pelayanan pendaftaran tanah pertama kali, salah satu persyaratan untuk pengakuan hak adalah adanya bukti pemilikan tanah/ alas hak sebagaimana diatur dalam Peraturan Kepala Badan Pertanahan Nasional Nomor 1 Tahun 2010 tentang Standar 
Pelayanan dan Pengaturan Pertanahan (PerkaBPN 1 tahun 2010). Dalam pelaksanaannya, alas hak yang diperlukan adalah surat pelepasan tanah adat dari kepala suku pada masyarakat hukum adat tersebut. Beberapa kondisi yang terjadi di Papua adalah adanya penerbitan surat pelepasan hak ulayat atas objek bidang tanah yang sama beberapa kali sehingga menimbulkan permasalahan pertanahan di kemudian hari. Salah satu penyebab terjadinya kondisi di atas adalah belum adanya penetapan hak ulayat masyarakat hukum adat oleh pemerintah daerah. Selain itu, munculnya sengketa dan konflik mengenai penetapan subjek pemilik dan penguasa tanah, subjek penerima pembayaran ganti kerugian serta nilai ganti kerugian yang harus diterima oleh masing-masing subjek sering kali menjadi penghambat pengadaan tanah sebagaimana disebutkan di beberapa penelitian terkait pengadaan tanah dengan objek tanah ulayat (Dewi et al., 2020).

Penelitian terkait penetapan hak ulayat masyarakat hukum adat belum banyak dilakukan, hasil penelitian Badan Pemeriksa Keuangan Perwakilan Provinsi Papua (BPK Papua) (2014) hanya menerangkan berbagai faktor yang menjadi penyebab timbulnya konflik terkait hak ulayat antara pemerintah dengan masyarakat hukum adat, Suharyo (2019) meneliti tentang perlindungan hukum pertanahan adat di Papua dalam negara kesejahteraan, sedangkan Widowati et al. (2014) memberikan gambaran mengenai konsep dan pola hak menguasai atas lahan pada kawasan hutan adat yang dilindungi di Indonesia serta bagaimana sistem dan tata cara pendaftaran tanah hutan adat. Penelitian yang dilakukan oleh Yoatili (2015) menunjukkan bahwa persoalan mengenai tanah hak ulayat masyarakat hukum adat belum dapat terselesaikan walaupun telah ada otonomi khusus bagi Papua dan Perdasus 23 tahun 2008. Berkaitan dengan kepemilikan tanah hingga saat ini masih menjadi problem yang krusial yang disebabkan oleh beberapa hal diantaranya 1) pemerintah belum mengakui adanya hak rakyat dalam kepemilikan hak ulayat; 2) pemerintah mengambil banyak tanah masyarakat secara paksa untuk dilepaskan menjadi tanah negara; dan 3) belum jelasnya batas hak ulayat menyebabkan sengketa tanah. Dari beberapa penelitian terdahulu yang memiliki keterkaitan dengan hak ulayat masyarakat hukum adat, belum ada yang secara spesifik membahas pentingnya penetapan hak ulayat masyarakat hukum adat di Papua terkait pelayanan pertanahan.

Dalam penelitian ini akan dibahas kaitan penetapan hak ulayat masyarakat hukum adat dengan pelayanan pertanahan yang ada di Papua, hingga saat ini belum adanya pemerintah daerah di Papua yang menyusun peraturan daerah tentang penetapan hak ulayat masyarakat hukum adat, padahal tidak sedikit kasus pertanahan terjadi akibat belum adanya kejelasan mengenai hak ulayat masyarakat hukum adat. Pemerintah daerah 
di Papua terkesan enggan memberikan pengakuan terhadap adanya hak ulayat masyarakat hukum adat.

\section{B. Metode Penelitian}

Metodo yang penulis gunakan dalam penelitian ini adalah penelitian hukum normatif, dengan pendekatan studi kasus dan analisis data kualitatif. Analisis bertumpu pada data sekunder sebagai hasil studi pustaka yang dilakukan dengan tahapan 1) pengumpulan data; 2) analisis data; dan 3) penarikan kesimpulan. Data yang digunakan dalam penelitian ini bersumber dari data-data sekunder berupa peraturan perundangundangan, buku-buku, jurnal, karya ilmiah di bidang hukum, artikel, surat kabar dan website serta laporan penelitian yang berkaitan dengan objek penelitian.

Penelitian ini dilakukan dengan mengelompokkan berbagai data yang telah berhasil dikumpulkan untuk selanjutnya dipilah untuk mendapatkan data yang relevan dengan permasalahan yang diteliti. Selanjutnya, data tersebut dipelajari dan ditelaah dengan cermat untuk mendapatkan gambaran umum mengenai hal-hal yang berkaitan dengan persoalan yang sedang diteliti, gambaran mengenai permasalahan tersebut kemudian di uraikan secara deskriptif s analisis supaya mudah dipahami.

\section{Perkembangan Penetapan Hak Ulayat Masyarakat Hukum Adat di Papua}

Pada sistem hukum adat, dikenal dua jenis hak atas tanah yang saling mempengaruhi dan saling terkait antara jenis hak atas tanah yang satu dengan yang lainnya. Jenis hak atas tanah yang dimaksud adalah hak persekutuan hukum atau hak ulayat dan hak perorangan. Sitorus (2011) dalam Sembiring (2016) menegaskan bahwa pada kondisi umum, mendapatkan tanah ulayat tidak dimungkinkan tanpa izin dari masyarakat hukum adat pemilik hak ulayat. Pada umumnya, tanah ulayat dipunyai oleh kelompok adat atau suku tertentu sesuai letak tanah itu. Pengelolaan tanah ulayat tidak sama antara suku yang satu dengan suku yang lain, itu sesuai dengan suku yang mengusai tanah ulayat tersebut (Pellokila, 2021). Dalam pembahasan hukum agraria di Indonesia, Harsono (2003) menjelaskan hak ulayat adalah sebutan yang telah disetujui oleh para ahli hukum supaya masyarakat hukum adat paham dengan tanah dalam kawasannya, yang kita kenal dengan istilah tanah ulayat dan merupakan lebensraum atau ruang hidup bagi masyarakat tersebut sepanjang masa. Hak Ulayat disebut dengan istilah beschikkingsrecht atau hak pertuanan (Dirkareshza et al., 2020).

Hak ulayat dapat dipahami dalam berbagai pengertian. Poro et al. (2021) mendefinisikan hak ulayat sebagai himpunan kewajiban dan kekuasaan yang dimiliki oleh masyarakat hukum adat. Kartasapoetra berpendapat bahwa hak ulayat adalah hak yang 
paling tinggi atas tanah, yang dapat dipunyai oleh suatu himpunan hukum berwujud suku atau desa demi memberikan jaminan keteraturan dalam pengusahaan tanah tersebut (Lestari \& Sukisno, 2021). Dari perspektif peraturan perundang-undangan, pada UndangUndang Dasar 1945 hak ulayat disebut dengan hak-hak tradisional masyarakat hukum adat. Pasal 18B ayat (2) menunjukkan bahwa Negara memberikan pengakuan dan penghormatan terhadap masyarakat hukum adat sebagai sebuah kesatuan termasuk hak tradisional yang masih hidup dan tidak bertentangan dengan prinsip NKRI dan perkembangan bangsa. Undang-Undang Nomor 5 Tahun 1960 (UUPA) memberikan penjelasan terkait hak ulayat dan hak-hak yang serupa itu adalah yang di dalam perpustakaan hukum disebut dengan "beschikkingrecht" sebagaimana tercantum pada penjelasan undang-undang tersebut.

Dalam memahami konsep hak ulayat masyarakat hukum adat, selain memahami hak ulayat juga perlu memahami masyarakat hukum adat. Dalam Peraturan Menteri Negara Agraria/ Kepala Badan Pertanahan Nasional Nomor 5 Tahun 1999 (PMNA 5 tahun 1999) yang berisi panduan penanganan persoalan terkait hak ulayat masyarakat hukum adat, yang dimaksud masyarakat hukum adat adalah himpunan orang yang mengikatkan diri kepada sebuah pranata hukum adatnya sebagai warga bersama sebuah perhimpunan hukum yang didasari pada adanya kesamaan tempat tinggal atau berdasarkan pada keturunan. Definisi ini diperluas dalam Peraturan Menteri ATR/ Kepala BPN Nomor 18 Tahun 2019, kesatuan masyarakat hukum adat merupakan himpunan orang yang identitas budaya yang sama, hidup secara turun-temurun dalam kawasan tertentu berdasarkan pada kesamaan tempat tinggal atau keturunan, mempunyai benda adat kepunyaan bersama serta pranata hukum adatnya sepanjang masih hidup, tidak bertentangan dengan perkembangan masyarakat serta berpegang pada prinsip NKRI. Masyarakat hukum adat dalam Peraturan Menteri Dalam Negeri Nomor 52 Tahun 2014 adalah WNI yang mempunyai ciri-ciri yang unik, tinggal secara berkelompok dengan rukun patuh pada hukum adatnya, mempunyai hubungan dalam keturunan dengan leluhur dan/atau lingkungan hidup yang sama, memiliki ikatan yang kuat dengan tanah dan lingkungan tempat tinggal, serta terdapat sistem nilai yang mendefinisikan sistem politik, ekonomi, hukum, sosial, budaya dan mengelola satu kawasan tertentu dengan sistem turun temurun. Pada konteks Papua dalam UU Otsus dan Perdasus 23 tahun 2008, masyarakat hukum adat adalah orang yang sejak kelahirannya hidup dalam kawasan tertentu sebagai masyarakat asli Papua, mengikatkan diri serta patuh pada suatu hukum adat dengan rasa solidaritas yang tinggi di antara para anggotanya. 
Uraian tentang hak ulayat dan masyarakat hukum adat dapat memberikan gambaran tentang hak ulayat masyarakat hukum adat. Harsono (2008) menerangkan bahwa hak ulayat masyarakat hukum adat adalah himpunan kewajiban dan kekuasaan yang dimiliki oleh masyarakat hukum adat, yang berkaitan dengan tanah yang berada dalam lingkungan tanah kawasannya. Pada Perdasus 23 tahun 2008 hak ulayat masyarakat hukum adat disebut dengan hak ulayat masyarakat hukum adat atas tanah memiliki pengertian hak perhimpunan yang dimiliki oleh suatu masyarakat hukum adat atas suatu kawasan yang menjadi tempat tinggal para anggota masyarakatnya yang terdiri dari kewenangan untuk mengelola tanah termasuk semua yang terkandung di dalamnya sesuai dengan peraturan yang berlaku. Hak ulayat masyarakat hukum adat dalam tulisan ini adalah mencakup hak ulayat serta hak perorangan warga masyarakat hukum adat.

Penetapan hak ulayat masyarakat hukum adat di Papua diatur dalam berbagai tingkatan peraturan perundang-undangan. Dari tingkat konstitusi, undang-undang, sampai pada peraturan daerah telah ada payung hukum yang mengatur tentang hal itu. Pada UUD 1945, terdapat Pasal 18B ayat (2) yang mengatur bahwa pengakuan terhadap masyarakat hukum adat termasuk hak tradisionalnya diatur dalam undang-undang. Sebagai turunan dari UUD 1945, UU Otsus Papua mengatur perlindungan hak-hak masyarakat adat dalam satu bab khusus yakni pada Bab IX yang terdiri dari 2 pasal di dalamnya. Untuk mengatur secara lebih khusus, Pemerintah Papua telah menerbitkan beberapa Perdasus terkait dengan pengakuan masyarakat hukum adat beserta hak ulayatnya. Pada Undang-Undang Nomor 23 Tahun 2014 tentang Pemerintah Daerah (UU Pemda) disebutkan dalam lampirannya bahwa pengakuan keberadaan masyarakat hukum adat yang berada di daerah kabupaten/kota merupakan bagian dari urusan pemerintahan konkuren bidang lingkungan hidup yang menjadi urusan pemerintah daerah provinsi dan kabupaten/kota. Pengaturan mengenai hal itu juga diatur dalam PMNA 5 tahun 1999 yang dicabut dengan Peraturan Menteri Agraria dan Tata Ruang/ Kepala Badan Pertanahan Nasional (Permen ATR/BPN) Nomor 9 Tahun 2015 selanjutnya dicabut dengan Permen ATR/BPN Nomor 10 Tahun 2016 yang juga dicabut, saat ini yang berlaku adalah Permen ATR/BPN Nomor 18 Tahun 2019 yang mengatur mengenai mekanisme penatausahaan tanah ulayat suatu kesatuan masyarakat hukum adat. Pada tingkatan yang sama, pengakuan dan perlindungan masyarakat hukum adat diatur dengan Peraturan Menteri Dalam Negeri Nomor 52 Tahun 2014 (Permendagri 52 tahun 2014). Tidak hanya itu, Badan Informasi Geospasial (BIG) juga mengatur pemetaan wilayah masyarakat hukum adat melalui Peraturan BIG Nomor 12 Tahun 2017. Yang terbaru, Presiden Joko Widodo memberikan perhatian khusus terhadap Papua dengan menerbitkan Instruksi Presiden 
Nomor 9 Tahun 2020 tentang Percepatan Pembangunan Kesejahteraan di Provinsi Papua dan Provinsi Papua Barat yang salah satu isinya berisi perintah presiden kepada Menteri ATR/Kepala BPN untuk meningkatkan kepastian hukum hak atas tanah melalui sertipikasi hak atas tanah, penataan dan publikasi batas kawasan hutan dan non hutan dalam skala kadaster, dan pendaftaran tanah adat/ ulayat sesuai hasil inventarisasi masyarakat hukum adat dan tanah adat/ulayat yang ditetapkan oleh pemerintah daerah dalam Perdasus atau predasi.

Papua sebagai salah satu daerah dengan otonomi khusus, telah menerbitkan beberapa peraturan daerah khusus (dikenal dengan perdasus). Beberapa perdasus yang terkait dengan pengakuan masyarakat hukum adat beserta hak tradisionalnya yakni 1) Perdasus Nomor 21 Tahun 2008 tentang Pengelolaan Hutan Berkelanjutan di Provinsi Papua; 2) Perdasus Nomor 22 Tahun 2008 yang mengatur mengenai pelestarian dan pemanfaatan sumber daya alam (SDA) masyarakat hukum adat Papua; dan Perdasus Nomor 23 Tahun 2008.

Tahapan pengakuan terhadap masyarakat hukum adat secara umum dilaksanakan sesuai dengan Permendagri 52 tahun 2014. Pada tahap awal, bupati/walikota membentuk panitia masyarakat hukum adat kabupaten/kota yang ditetapkan dengan keputusan bupati/walikota. Selanjutnya, pengakuan dan perlindungan masyarakat hukum adat dilakukan melalui beberapa tahapan meliputi 1) identifikasi masyarakat hukum adat; 2) verifikasi dan validasi masyarakat hukum adat; dan 3) penetapan masyarakat hukum adat. Tahapan identifikasi dilaksanakan dengan mengikutsertakan masyarakat untuk mencermati 1) sejarah masyarakat hukum adat; 2) wilayah adat; 3) hukum adat; 4) harta kekayaan dan/atau benda-benda adat; dan 5) kelembagaan/sistem pemerintahan adat. Setelah itu, panitia melakukan verifikasi dan validasi hasil identifikasi. Hasil dari proses tersebut diumumkan kepada masyarakat hukum adat setempat selama satu bulan. Berdasarkan hasil verifikasi dan validasi yang telah diumumkan, panitia menyampaikan rekomendasi kepada bupati/walikota untuk menetapkan pengakuan dan perlindungan masyarakat hukum adat.

Sebagai daerah dengan otonomi khusus, Papua memiliki perdasus yang mengatur penetapan hak ulayat masyarakat hukum adat yakni perdasus 23 tahun 2008. Hak ulayat dan/atau hak perorangan warga masyarakat hukum adat diakui keberadaannya berdasarkan hasil penelitian di kabupaten/kota. Penelitian itu dilaksanakan oleh panitia yang terdiri dari 1) pakar hukum adat; 2) penguasa adat yang berwenang dalam masyarakat hukum adat; 3) lembaga swadaya masyarakat; 4) pejabat dari BPN; 5) pejabat dari bagian hukum kantor bupati/walikota; 6) pejabat dari instansi kehutanan dan 
pertambangan; dan 7) pejabat dari instansi terkait. Panitia itu ditetapkan dengan keputusan bupati/walikota untuk selanjutnya meneliti tentang beberapa hal meliputi 1) sistem hukum adat serta struktur penguasa adat yang dipatuhi oleh anggotanya; 2) sistem pengelolaan hak ulayat masyarakat hukum adat sesuai dengan hukum adat asli;3) pemimpin adat yang memiliki kuasa dalam mengatur pengelolaan hak ulayat masyarakat hukum adat; dan 4) batas kawasan yang dianggap sebagai hak ulayat masyarakat hukum adat oleh masyarakat hukum adat setempat. Panitia menggunakan peta dasar dengan skala minimal 1:50.000 dengan melibatkan pemimpin adat setempat dan pemimpin adat yang wilayahnya berbatasan. Titik batas yang telah disetujui dipasang tanda batas permanen. Persetujuan batas ditetapkan dengan berita acara persetujuan batas yang ditandatangani oleh beberapa pihak terkait meliputi 1) pemimpin adat yang berwenang; pemimpin adat yang wilayahnya berbatasan; 3) ketua panitia peneliti; 4) kepala distrik; dan 5) kepala kelurahan atau kampung. Hasil penelitian yang telah didapat diserahkan oleh panitia kepada bupati/walikota dalam bentuk laporan. Laporan itu disertai dengan lampiran peta batas hak ulayat masyarakat hukum adat yang telah disetujui oleh para pihak yang telah menyetujui batas tersebut. Berdasarkan hasil penelitian, bupati/walikota dan/atau gubernur menetapkan keputusan tentang adanya hak ulayat masyarakat hukum adat. Keputusan tersebut menyatakan bahwa hak ulayat masyarakat hukum adat masih ada dengan disertai 1) nama asli yang dikenal dalam masyarakat hukum adat; 2) pemimpin adat yang memiliki kuasa dalam mengatur pengelolaan hak ulayat masyarakat hukum adat; 3) lampiran peta hasil penelitian.

Penetapan hak ulayat masyarakat hukum adat telah diamanatkan melalui berbagai tingkatan peraturan perundang-undangan, namun pelaksanaannya berbeda, nyatanya belum ada pengakuan hak ulayat masyarakat hukum adat di Papua. Selain dipengaruhi oleh peran pemerintah, juga dipengaruhi oleh pihak masyarakat hukum adat. Yang terjadi di Papua sejalan dengan penjelasan Mujiati et al. (2019) bahwa eksistensi tanah ulayat beserta masyarakat hukum adatnya semata-mata klaim pihak masyarakat hukum adat yang diiringi melemahnya berbagai pranata adat mereka termasuk tradisi, hukum adat serta wilayah adat. Fakta yang terjadi dalam berbagai kesempatan adalah 'pemalangan' oleh masyarakat hukum adat setempat terhadap bidang tanah yang dikuasai oleh pihakpihak di luar masyarakat hukum adat tersebut. Sebagai contoh, 'pemalangan' Stadion Lukas Enembe oleh masyarakat hukum adat setempat. Ini berkaitan dengan 'pemalangan' yang dilakukan oleh suku Ohee menyikapi masalah pembayaran ganti kerugian hak ulayat dan pembangunan jalan alternatif di sekitar stadion (CNN Indonesia, 2021). 
Pemerintah daerah di Papua enggan memberikan pengakuan masyarakat hukum adat. Hal tersebut dibuktikan dengan belum adanya peraturan daerah baik provinsi maupun kabupaten/kota tentang pengakuan hak ulayat masyarakat hukum adat. Dari 28 kabupaten dan 1 kota yang menjadi bagian dari Papua, baru Kabupaten Jayapura yang mulai menginisiasi pengakuan hak ulayat masyarakat hukum adat dengan menerbitkan beberapa produk hukum sebagai dasar pengakuan, perlindungan dan pemberdayaan masyarakat adat di Kabupaten Jayapura. Produk hukum yang dimaksud terdiri dari 1) Peraturan Daerah Kabupaten Jayapura Nomor 8 Tahun 2016 tentang Kampung Adat; 2) Peraturan Daerah Kabupaten Jayapura Nomor 2 Tahun 2018 tentang Penyelenggaraan Pengakuan, Perlindungan dan Pemberdayaan Masyarakat Hukum Adat; 3) Keputusan Bupati Jayapura Nomor 320 Tahun 2014 tentang Pembentukan 36 Kampung Adat di Kabupaten Jayapura; dan 4) Keputusan Bupati Jayapura Nomor 319 Tahun 2014 tentang Pengakuan dan Perlindungan Masyarakat Hukum Adat di Kabupaten Jayapura. Langkah maju Kabupaten Jayapura ini merupakan perwujudan salah satu misi yaitu mendorong keberdayaan dan kemajuan masyarakat adat yang mencakup usaha penguatan keberadaan masyarakat adat, serta pembangunan kampung adat (Pemerintah Kabupaten Jayapura, 2017). Sebagai usaha menuju pengakuan hak ulayat masyarakat hukum adat di sana, Pemerintah Kabupaten Jayapura membentuk Gugus Tugas Masyarakat Adat (GTMA). GTMA Jayapura merupakan lembaga adhoc yang didukung oleh berbagai pihak baik dari pemerintah daerah, lembaga swadaya masyarakat, tenaga ahli dari perguruan tinggi yang secara aktif berkoordinasi dengan kepala distrik, kepala kampung dan tokoh-tokoh adat di kawasan masyarakat hukum adat. Langkah maju di Kabupaten Jayapura saat ini disusul oleh Kabupaten Sarmi melalui Gugus Tugas Reforma (GTRA) Sarmi bersama Multi Sector Forum (MSF) menginisiasi pemetaan sosial dan spasial wilayah masyarakat hukum adat. Pemerintah Kabupaten Sarmi membentuk tim melibatkan berbagai pihak sebagaimana yang diamanatkan dalam Perdasus 23 tahun 2008 untuk melaksanakan pemetaan sosial dan spasial wilayah masyarakat hukum adat. Tim itu memiliki tugas melakukan identifikasi, verifikasi dan validasi keberadaan masyarakat hukum adat di Kabupaten Sarmi. Hingga saat ini, tim tersebut telah memetakan 4 dari 5 wilayah adat yang ada di Kabupaten Sarmi. Kabupaten/kota lain selain Jayapura dan Sarmi belum menunjukkan adanya inisiatif dari pemerintah daerah untuk mulai melaksanakan tahapan pengakuan hak ulayat masyarakat hukum adat di wilayah kabupaten/kota tersebut.

Komposisi panitia penelitian keberadaan hak ulayat masyarakat hukum adat telah diatur dalam Pasal 3 ayat (2) Perdasus 23 tahun 2008. Susunan panitia penelitian itu terdiri dari 1) para pakar hukum adat; 2) penguasa adat yang berwenang atas hak ulayat 
masyarakat hukum adat yang bersangkutan; 3) lembaga swadaya masyarakat; 4) pejabat dari BPN; 5) pejabat dari bagian hukum kantor bupati/walikota; 6) pejabat dari instansi yang menyelenggarakan urusan di bidang kehutanan; 7) pejabat dari instansi yang menyelenggarakan urusan di bidang pertambangan; dan 8) pejabat dari instansi terkait lainnya. Dalam meneliti keberadaan hak ulayat suatu masyarakat hukum adat, tim itu berkoordinasi dengan kepala distrik dan kepala kampung serta mengikutsertakan peran masyarakat hukum adat yang tinggal pada kawasan tersebut.

Pembentukan panitia penelitian di Kabupaten Sarmi telah dilaksanakan. Susunan dari panitia itu melibatkan berbagai pihak terkait. Panitia ini diketuai oleh sekretaris daerah, dengan sekretaris dari badan perencanaan dan pembangunan daerah (Bappeda) serta wakil sekretaris dari dinas lingkungan hidup. Anggota panitia ini terdiri dari 1) Lembaga Masyarakat Adat (LMA) Sarmi dan Dewan Adat Daerah (DAD) Sarmi sebagai lembaga adat yang berwenang atas masyarakat hukum adat di Kabupaten Sarmi; 2) lembaga swadaya masyarakat meliputi LSM KIPRa, LSM KIPAS, AMAN, RAPI; 3) Kantor Pertanahan Kabupaten Sarmi; 4) Bagian Hukum Setda Kabupaten Sarmi; 4) Kantor Cabang Dinas Kehutanan; 5) beberapa instansi terkait meliputi Dinas Pekerjaan Umum dan Penataan Ruang, Dinas Perumahan dan Kawasan Permukiman, Dinas Pariwisata, Dinas Pemberdayaan Masyarakat Kampung, Dinas Komunikasi dan Informasi, Badan KESBANGPOL dan UPT Geospasial Universitas Papua.

Kementerian ATR/BPN turut mengambil peran dalam proses pengakuan hak ulayat masyarakat hukum serta tindak lanjut dari pengakuan tersebut. Dalam proses pengakuan hak ulayat sebagaimana diatur dalam Perdasus 23 tahun 2008, Kementerian ATR/BPN melalui Kantor Pertanahan Kabupaten/Kota di seluruh Papua ikut menjadi bagian dari panitia penelitian keberadaan hak ulayat masyarakat hukum adat yang pembagian tugas masing-masing pihak akan ditetapkan dengan keputusan bupati/walikota. Setelah hasil penelitian menunjukkan bahwa benar-benar masih ada hak ulayat masyarakat hukum adat di kawasan tersebut selanjutnya ditetapkan dengan peraturan daerah kabupaten/kota, Kantor Pertanahan Kabupaten/Kota mengambil peran dalam pengukuran dan pemetaan hak ulayat masyarakat hukum adat. Pengukuran dan pemetaan kadastral tersebut dilaksanakan sesuai dengan batas-batas hak ulayat masyarakat hukum adat yang telah disetujui dan telah dituangkan dalam berita acara persetujuan batas. Selanjutnya, hasil pengukuran itu dipetakan pada peta pendaftaran tanah serta dicatatkan dalam daftar tanah. Di kemudian hari, peta pendaftaran dan daftar tanah tersebut menjadi acuan bagi Kantor Pertanahan Kabupaten/Kota dalam pemberian hak atas tanah bagi subjek yang mengajukan permohonan atas suatu bidang tanah. 


\section{Urgensi Penetapan Hak Ulayat Masyarakat Hukum Adat terkait Kebijakan Pelayanan Pertanahan di Papua}

Kementerian ATR/BPN sebagai lembaga yang mendapat tugas menyelenggarakan urusan pemerintahan di bidang agraria/pertanahan dan tata ruang memiliki berbagai kelompok dan jenis pelayanan. Pelayanan tersebut disebutkan dalam Pasal 5 PerkaBPN 1 tahun 2010. Kelompok pelayanan yang ada di Kementerian ATR/BPN melalui Kantor Pertanahan Kabupaten/Kota terdiri dari 1) pendaftaran tanah pertama kali; 2) pemeliharaan data pendaftaran tanah; 3) pencatatan dan informasi pertanahan; 4) pengukuran bidang tanah); 5) pengaturan dan penataan pertanahan; dan 6) pengelolaan pengaduan. Dalam kelompok pelayanan pendaftaran tanah pertama kali terdapat beberapa jenis pelayanan meliputi 1) konversi, pengakuan dan penegasan hak; 2) pemberian hak milik, hak guna bangunan, hak pakai dan hak pengelolaan sesuai dengan subjek yang dapat memilikinya; 3) wakaf dari tanah belum bersertipikat dan dari tanah negara; 4) P3MB/Prk.5; 5) pendaftaran hak milik atas satuan rumah susun; dan 6) pemberian hak guna usaha bagi perorangan dan badan hukum.

Pada masing-masing jenis pelayanan dalam rangka pendaftaran tanah pertama kali, terdapat persyaratan yang harus dilengkapi. beberapa jenis pelayanan pendaftaran tanah pertama kali terdapat beberapa persyaratan yang sama antara satu pelayanan dengan yang lain. Persyaratan yang dimaksud meliputi 1) formulir permohonan yang telah diisi dan ditandatangani pemohon di atas materai cukup; 2) fotokopi identitas pemohon; 3) bukti perolehan tanah/alas hak; dan 4) fotokopi SPPT PBB Tahun berjalan yang telah dicocokkan dengan aslinya oleh petugas loket.

Salah satu persyaratan terpenting dalam permohonan pendaftaran tanah pertama kali adalah bukti perolehan tanah/alas hak. Berbagai macam alat bukti dapat menjadi alat bukti tertulis mengenai kepemilikan tanah sebagaimana diatur dalam Pasal 60 Peraturan Menteri Negara Agraria (PMNA) Nomor 3 Tahun 1997. Satu diantaranya ialah akta dibawah tangan yang berisi pemindahan hak yang dibubuhi tanda tangan sebagai bukti kesaksian oleh kepala adat. Dalam konteks pelayanan pertanahan di Papua, alat bukti tersebut dapat dipahami sebagai akta pelepasan hak ulayat masyarakat hukum adat (dikenal dengan surat pelepasan hak atas tanah adat) kepada pihak yang membutuhkan tanah sebagai mana disebutkan dalam Pasal 8 ayat (3) Perdasus 23 tahun 2008.

Terdapat perbedaan antara apa yang diatur dalam Perdasus 23 tahun 2008 dengan apa yang dilaksanakan di Papua. Sebagaimana diatur dalam Pasal 8, pelepasan sebagian atau seluruh hak ulayat masyarakat hukum adat kepada pihak yang memerlukan tanah dengan ganti kerugian yang disepakati bersama seharusnya dilakukan dengan akta 
autentik. Terhadap sebagian atau seluruh hak yang dilepaskan, tanahnya dilepaskan kepada negara menjadi tanah yang langsung dikuasai oleh negara. Pada kenyataannya yang terjadi justru penguasa atau pimpinan masyarakat hukum adat setempat memberikan keterangan bahwa suatu bidang tanah merupakan milik perorangan warga masyarakat hukum adat yang bersangkutan. Dari hak perorangan tersebut selanjutnya dibuatkan surat pernyataan pelepasan hak atas tanah adat dari pemegang hak perorangan warga masyarakat hukum adat kepada pihak yang membutuhkan tanah, bukan dilepaskan kepada negara untuk menjadi tanah yang langsung dikuasai oleh negara.

Dewasa ini, pembuatan surat pelepasan hak atas tanah adat berpotensi menimbulkan sengketa di kemudian hari. Hal itu dapat terjadi karena belum ada pengakuan hak ulayat masyarakat hukum adat yang diterbitkan oleh pemerintah daerah. Tidak ada jaminan yang kuat secara hukum bahwa pemegang hak ulayat masyarakat hukum adat tersebut adalah yang benar-benar berhak atas bidang tanah tersebut. Pada saat ini terjadi beberapa kali sengketa yang terjadi antara beberapa suku yang berbatasan atas suatu bidang tanah.

Berbagai kasus sengketa hak ulayat pernah terjadi di Papua. Leonita (2008) dalam Yoatili (2015) menjelaskan tentang kasus antara PT Freeport Indonesia dengan masyarakat hukum adat Kamoro dan Amungme di Kabupaten Mimika. Sejak PT Freeport Indonesia menambang masyarakat hukum adat dipindahkan ke lokasi lain di luar area penambangan. Kekuasaan tersebut didapat melalui pengesahan kontrak karya pada tahun 1967. Masyarakat hukum adat tersebut dipindahkan dengan alasan terkena dampak akibat pembuangan limbah yang dihasilkan dari proses penambangan. Amahorseya (2008) dalam menyebutkan bahwa sengketa tanah terkait hak ulayat juga terjadi antara Pemerintah Kabupaten Nabire dengan masyarakat hukum adat suku Wate (Yoatili, 2015).

Pemerintah Kabupaten Nabire tidak memanfaatkan hak ulayat yang telah dilepaskan oleh masyarakat hukum adat suku Wate secara sukarela pada tahun 1966. Hak ulayat masyarakat hukum adat suku Wate diserahkan kepada Pemerintah Kabupaten Nabire melalui kesepakatan bersama antara kepala kampung Oyehe dengan warga Nabire nomor 001/KPRS/51966 tanggal 06 Mei 1966. Dalam kesepakatan bersama itu diserahkan 3 bidang tanah untuk kepentingan umum di Nabire di antara untuk kepentingan pembangunan banda udara Nabire. Namun, seiring berjalannya waktu, bidang tanah tersebut tidak digunakan sebagaimana kesepakatan yang telah dibuat. Kasus lainnya juga disebutkan oleh Yoatili (2006) terjadi antara Pemerintah Daerah Papua dengan suku Jautunyi yang merupakan bagian dari masyarakat hukum adat Ormu yang saat ini termasuk dalam wilayah Kota Jayapura. Masyarakat beranggapan bahwa Pemerintah Daerah Papua merekayasa adanya pelepasan 6000 hektar menjadi tanah yang langsung dikuasai oleh 
negara melalui kesepakatan bersama Overeenkomst 1959. Padahal, kepala suku yang dikenal dengan Ondoafi dari suku Ormu merasa tidak pernah melakukan pelepasan hak ulayat terhadap tanah seluas 6000 hektar tersebut. Akibatnya, hingga saat ini masyarakat hukum adat Ormu masih menuntut ganti kerugian terhadap tanah-tanah yang telah dikuasai dan dimanfaatkan oleh pemerintah serta pengakuan terhadap eksistensi hak ulayat masyarakat hukum adat Ormu (Yoatili, 2015). Gefilem (2016) menerangkan bahwa sengketa akibat penggunaan pelepasan adat sebagai dasar jual beli hak atas tanah ulayat menjadi hak perorangan sering terjadi di Papua (Ivan \& Jamin, 2018). Surat pelepasan tanah adat berfungsi sebagai bukti peralihan atas suatu bidang tanah yang dibuat oleh pihak yang diberi kewenangan melalui Pasal 43 ayat (4) UU Otsus yakni lembaga masyarakat adat. Surat itu selanjutnya digunakan sebagai persyaratan agar kantor pertanahan menerbitkan sertipikat atas bidang tanah tersebut (Ivan \& Jamin, 2018).

Beberapa kasus di atas menjadi salah satu faktor yang menjadikan penetapan hak ulayat masyarakat hukum adat di Papua. Kasus bentrokan antara suku Nafri dan suku Enggros akibat permasalahan hak tanah (CNN Indonesia, 2020) menjadi salah satu fakta pendukung bahwa belum adanya penetapan hak ulayat masyarakat menjadi salah satu timbulnya konflik antar suku di Papua. Beberapa hal yang menjadi sebab perlunya segera dilaksanakan penetapan hak ulayat masyarakat hukum adat berkaitan dengan pelayanan pertanahan di Papua. Pertama, penetapan ini merupakan amanat UU Otsus yang seharusnya segera dilaksanakan oleh pemerintah daerah. Hal itu tercantum dalam Pasal 43 UU Otsus yang menyatakan bahwa Pemerintah Papua wajib mengakui hak masyarakat adat yang tahapan penelitiannya diatur dalam Perdasus 23 tahun 2008.

Kedua, penetapan hak ulayat masyarakat hukum adat akan mengurangi potensi sengketa pertanahan yang objeknya merupakan bagian dari hak ulayat tersebut. Ketika peraturan daerah tentang pengakuan masyarakat telah ditetapkan dengan dilengkapi daftar nama dan data spasial batas-batas wilayah hak ulayat tentu akan memberikan kepastian hukum kepada pemegang hak ulayat tersebut. Selain itu, penyelesaian sengketa akan lebih mudah karena batas dan pemegang hak ulayat sudah jelas. Ketiga, pendaftaran tanah pertama kali terhadap bidang tanah yang telah ditetapkan sebagai bagian hak ulayat akan semakin mudah. Hal itu disebabkan karena kantor pertanahan dengan yakin menerbitkan hak atas pemegang hak dengan mengacu pada peta pendaftaran dan daftar tanah yang telah memuat informasi terkait hak ulayat masyarakat hukum adat yang bersangkutan. Keempat, penetapan pemegang hak ulayat masyarakat hukum adat merupakan kebutuhan negara sebagai upaya memberikan jaminan kepastian hukum. Sumardjono (2016) dalam Puri (2017) mengungkapkan bahwa hukum nasional yang 
berlaku di Indonesia menempatkan penetapan orang maupun badan hukum sebagai masyarakat hukum adat memerlukan sebuah pengakuan melalui peraturan daerah atau pun keputusan kepala daerah. Keputusan mengenai penetapan itu hanya bersifat deklaratoir.

\section{E. Kesimpulan}

Sebagaimana persoalan yang telah diuraikan pada pembahasan di atas, selanjutnya dapat ditarik kesimpulan sebagai berikut: pertama, walaupun telah diamanatkan dalam berbagai tingkatan peraturan perundang-undangan, penetapan hak ulayat masyarakat hukum adat melalui peraturan daerah belum dilaksanakan di seluruh kabupaten/kota di Papua. Kabupaten Jayapura dan Sarmi menginisiasi dengan melaksanakan pemetaan sosial dan spasial wilayah masyarakat hukum adat. Pemerintah melibatkan berbagai pihak terkait dalam tahap awal penelitian yang sedang dilaksanakan. Kedua, Penetapan hak ulayat masyarakat hukum adat menjadi hal penting untuk segera dilakukan karena 1) merupakan amanat UU Otsus yang belum dilaksanakan; 2) dapat mengurangi potensi sengketa pertanahan terkait hak ulayat; 3) proses pendaftaran tanah pertama kali akan semakin mudah; dan 4) penetapan hak ulayat masyarakat hukum merupakan kebutuhan negara.

Mengacu pada simpulan yang telah disampaikan, penulis menyampaikan beberapa saran sebagai berikut 1) kepala daerah perlu menginternalisasi pengakuan hak ulayat masyarakat hukum adat ke dalam visi misi; 2) pemerintah daerah perlu memprioritaskan anggaran untuk mendukung pelaksanaan penelitian sebagai cikal bakal pengakuan hak ulayat masyarakat hukum adat; dan 3) pemerintah perlu membangun komunikasi dengan berbagai pihak terkait penelitian mengenai keberadaan hak ulayat masyarakat hukum adat.

\section{Daftar Pustaka}

Badan Pemeriksa Keuangan Perwakilan Papua. (2014, Desember). Hak ulayat masyarakat hukum adat Papua. Diakses tanggal 27 Desember 2021 dari https://papua.bpk.go.id/wp-content/uploads/2014/12/Hak-Ulayat-Papua.pdf

Badan Pusat Statistik. (2019). Luas daerah dan jumlah pulau menurut provinsi 2019. Diakses tanggal 27 Desember 2021 dari https://www.bps.go.id/indikator/indikator/ view_data_pub/0000/api_pub/UFpWMmJZOVZ1ZTJnc1pXaHhDV1hPQT09/da_01/1 
Badan Pusat Statistik. (2021, Februari). Provinsi Papua dalam angka 2021. Diakses tanggal 27 Desember 2021 dari https://papua.bps.go.id/publication/2021/02/26/aae8d17cd6f20e6 1a590d990/provinsi-papua-dalam-angka-2021.html

Barnasaputri, I. I. (2021). Jalan Panjang Pengakuan Kesatuan Masyarakat Hukum Adat melalui Peraturan Daerah: Beberapa Persoalan yang Belum Selesai. Notaire, 4(1), 1-22. https://doi.org/10.20473/ntr.v4i1.22805.

Dewi, A. R., Sutaryono, S., Nurhikmahwati, A. (2020). Pemetaan Masalah Pengadaan Tanah dengan Objek Tanah Ulayat (Kasus Jalan Tol Padang-Sicincin). BHUMI: Jurnal Agraria dan Pertanahan, 6(2), 277-291. https://doi.org/10.31292/bhumi.v6i2.454.

Dirkareshza, R., Ibrahim, A. L., \& Pradana, R. (2020). Urgensi Hak Ulayat Terhadap Perlindungan Masyarakat Hukum Adat Di Indonesia. Jurnal Ilmiah Hukum De'Jure: Kajian Ilmiah Hukum, 5(1), 94-109.

Ivan, E. \& Jamin, M. (2018). Pembatalan Sertifikat Hak Milik Atas Tanah oleh Hakim di Pengadilan Tata Usaha Negara Jayapura. Jurnal Repertorium, 5(2), 64-77.

Kementerian Lingkungan Hidup dan Kehutanan. (2015). Indonesian national carbon accounting system data provinsi Papua. Diakses tanggal 27 Desember 2021 dari http://incas.menlhk.go.id/id/data/special-region-of-papua/

Lestari, R., \& Sukisno, D. (2021). Kajian Hak Ulayat di Kabupaten Kampar dalam Perspektif Peraturan Perundang-Undangan dan Hukum Adat. Jurnal Hukum Ius Quia Iustum, 28(1), 94-114. https://doi.org/10.20885/iustum.vol28.iss1.art5.

Mujiati, M., Mujiburohman, D. A., \& Khasanah, D. D. (2019). Pendaftaran tanah ulayat "suku" di provinsi nusa tenggara timur. Paper dipresentasikan pada Seminar Nasional Karakteristik Subjek, Objek, Permasalahan dan Solusi Tanah Ulayat/Adat dalam Pembangunan Pertanahan 2019.

Pellokila, J. R. Z. (2021). Analisis Penyelesaian Konflik Hak Ulayat pada Masyarakat Hukum Adat di Kabupaten Jayapura Papua. Jurnal Syntax Transformation, 2(8), 11111123. https://doi.org/10.46799/jst.v2i8.330.

Pemerintah Kabupaten Jayapura. (2017). Misi Kabupaten Jayapura. Diakses tanggal 07 Februari 2022 dari https://jayapurakab.go.id/pemerintahan/misi

Poro, S. M., Imron, A., \& Shanty, W. Y. (2021). Perlindungan Hukum Hak Tradisional Masyarakat Hukum Adat Terhadap Tindakan Individualisasi Tanah Ulayat untuk Tujuan Komersial. Bhirawa Law Journal, 2(1), 169-174. https://doi.org/10.26905/blj.v2i1.5857. 
Puri, W. I. (2017). Pluralisme Hukum Sebagai Strategi Pembangunan Hukum Progresif di Bidang Agraria di Indonesia. BHUMI: Jurnal Agraria dan Pertanahan, 3(1), 67-81. https://doi.org/10.31292/jb.v3i1.91.

Sembiring, J. (2016). Hak Menguasai Negara Atas Sumber Daya Agraria. BHUMI: Jurnal Agraria dan Pertanahan, 2(2), 119-132. https://doi.org/10.31292/jb.v2i2.65.

Solossa, M. (2021). Strategi pendekatan masyarakat hukum adat di Papua. Materi Rapat Koordinasi Gugus Tugas Reforma Agraria Kabupaten Sarmi di Kantor Bupati Sarmi, 30 Agustus 2021.

Suharyo. (2019). Perlindungan Hukum Pertanahan Adat di Papua dalam Negara Kesejahteraan. Jurnal Rechtsvinding Media Pembinaan Hukum Nasional, 8(3), 461-476. https://doi.org/10.33331/rechtsvinding.v8i3.330.

Widowati, D. A., Luthfi, A. N., \& Guntur, I. G. N. (2014). Pengakuan dan perlindungan hak atas tanah masyarakat hukum adat di kawasan hutan. Yogyakarta: STPN Press.

Yoatili, R. (2015). Implementasi Politik Hukum Perdasus Nomor 23 Tahun 2008 Tentang Hak Ulayat Masyarakat Hukum Adat Papua dalam Hukum Tanah Nasional. Jurnal Repertorium, 3, 152-160. (2020, 11 September). Bentrokan Antar-suku Papua Terkait Tanah Ulayat, 7 Lukaluka. CNN Indonesia. Diakses tanggal 25 Desember 2021 dari https://www.cnnindonesia.com/nasional/20200911112312-20-545280/bentrokanantar-suku-papua-terkait-tanah-ulayat-7-luka-luka (2021, 27 Agustus). Sempat Dipalang, Masalah Proyek Stadion Lukas Enembe Teratasi. CNN Indonesia. Diakses $07 \quad$ Februari 2022 dari https://www.cnnindonesia.com/nasional/20210827171841-12-686469/sempatdipalang-masalah-proyek-stadion-lukas-enembe-teratasi 